\title{
SKAITMENINIŲ VALIUTŲ KAINŲ PROGNOZAVIMAS NAUDOJANT GILIOJO MOKYMOSI ALGORITMĄ
}

\author{
Nijolè MAKNICKIENĖ, Kristina MIŠKINYTÉ* \\ Vilniaus Gedimino technikos universitetas, Verslo vadybos fakultetas, \\ Finansu inžinerijos katedra, Saulètekio al. 11, LT-10223, Vilnius, Lietuva \\ *El.paštas kristina.miskinyte@stud.vgtu.lt
}

\begin{abstract}
Santrauka. Kriptovaliutos vis dar yra finansų rinkos naujovè ir iki galo neištirta finansinis instrumentas. Tai išlaiko kriptovaliutas įdomia ir aktualia tema, tiek mokslininkams, tiek reguliacinems institucijoms bei investuotojams. Kriptovaliutų rinka yra auganti, nestabili ir nuolat besikeičianti, kas suteikia jai aukštą riziką ir plačias galimybes. Finansinis išmanymas ir toliaregiškas prognozavimas, nepasimetant pinigų vertès, rizikos ir nenuspėjamumo chaose yra ypač svarbus šiandieninèje ekonomikoje. Sudètingas kriptovaliutų rinkos pobūdis reikalauja plataus profilio duomenų kiekio, kuriam apdoroti taikomi ịvairūs metodai, tokie kaip statistinè, techninė, sentimentų, sprendimų bei kita analizè. Ankstesni tyrimai kriptovaliutų kainas numate dviem būdais: empirine analize ir mašinų mokymosi algoritmų analize. Šiame straipsnyje testuojamas giliojo mokymosi algoritmo taikymo galimybės kriptovaliutų kainų prognozavime. Taikant ilgalaikės trumpalaikės atminties tinklo (angl. long, shortterm network, toliau LSTM) algoritmą, prognozuojamas trumpalaikis kriptovaliutų kainų kitimas bei įvertinamas sugeneruotų duomenų tikslumas. Rezultatai parodè, kad giliojo mokymosi algoritmas kainas prognozuoja su maža paklaida ir tiksliai nuspejję kainos pokyčio tendenciją, kas leidžia teigti, kad giliojo mokymosi algoritmas yra efektyvi rizikos mažinimo priemonè finansų rinkoje.
\end{abstract}

Reikšminiai žodžiai: dirbtinis intelektas, gilusis mokymasis, LSTM, prognozavimas, kriptovaliutos, kriptovaliutu rinka.

\section{Ivadas}

Finansų rinkoje yra svarbus ne tik finansinis išmanymas bet ir toliaregiškas prognozavimas, nepasimetant pinigų vertès, rizikos ir nenuspejjamumo chaose. Kriptovaliutos nèra naujiena tiek finansų rinkai, tiek jos dalyviams. Aktyvų investavimą ir susidomèjimą šiuo finansiniu produktu iššaukė $2017 \mathrm{~m}$. ịvkęs kirpto-bumas. Tuometinė kriptovaliutu rinkos kapitalizacija sausio mėnesị siekè 17,000 mln. JAV doleriu, o jau birželį buvo pašokusi iki 90,000 mln. JAV dolerių. Jau 2018 gegužę tik dviejų didžiausių kriptovaliutų (Bitcoin ir Ethereum) bendra rinkos vertè coinmarketcap.com (2019) duomenimis siekè 160,9 milijardų JAV dolerių. Kapitalizacijos dydis ir kitimas yra vertès rodiklis suinteresuotam vartotojui ar investuotojui. Jis yra gaunama padauginus esamų rinkoje žetonų skaičių iš tuometinės jų kainos, taip išreiškiant investicijos dydị. Investavimo rizikos mažinimui vis dažniau pasitelkiamas dirbtinis intelektas, kuris automatizuoja ne tik fizinį bet ir protinị darbą, šiuo atveju - strateginį sprendimų prièmimą išanalizuojant tūkstančius duomenų sekundžių greičiu. Atlikta literatūros analizė parodè, kad yra tik keli moksliniai darbai, skirti analizuoti kriptovaliutų kainų prognozavimą taikant giliojo mokymosi algoritmus. Mokslinių tyrimų stoka skatina analizuoti šią tyrimo sriti giliau. Būtent todèl straipsnio tikslas - pritaikant giliojo mokymosi algoritmą nustatyto trumpalaikị kriptovaliutų kainos kitimą. Straipsnyje nagrinejjamas dirbtinis intelektas ir jo panaudojimas kriptovaliutų kainų prognozavimui, apžvelgti dažniausiai taikomi algoritmai bei palyginti trumpalaikių prognozuojamų kainų rezultatai su realiais duomenimis.

\section{Dirbtinio intelekto taikymo kriptovaliutų rinkoje apžvalga}

Pirmoje straipsnio dalyje apžvelgiamas dirbtinis intelektas, jo svarba ir taikymas kriptovaliutų rinkoje. Pagrindinis dėmesys skiriamas giliojo mokymosi algoritmo pritaikymo galimybės kriptovaliutų kainų prognozavimui bei rezultatų tikslumo nagrinèjimui.

Kriptovaliutos nèra nei naujas produktas, nei faktiniai pinigai, tai visiškai skaitmeninè vertès perdavimo priemonè, kurios naudojimo ir ateities galimybių aspektai yra vis dar tiriami ir teisiškai apibrěžiami. Kriptovaliutu pradžia laikomi 2009 metai, kai buvo pristatyta Bitcoin kriptovaliuta. Nepaisant to, intensyvus susidomėjimas ir 
naudojimas investiciniu pobūdžiu yra ganėtinai naujas reiškinys, kuris stokoja detalių tyrimų tiek ties kriptovaliutų rinkos kainų kitimu, tiek investavimu ir prognozavimu. Kriptovaliutų apibrěžimas yra dažnai tapatinamas su elektroninių pinigų sąvoka, kas teisiškai neatitinka elektroninių pinigų ir elektroninių pinigų įstaigų XIII-1094 įstatymo apibrèžtų būtinų sąlyga, tokių kaip plataus priimtinumo ar leidejjui privalomo išpirkimo. Lietuvos Bankas (2017) kriptovaliutas apibūdina kaip nereglamentuotus ir nereguliuojamus skaitmeninius pinigus, kurių išleidimo ị apyvartą negarantuoja centrinis bankas. Virtualūs pinigai arba kriptovaliuta literatūroje apibūdinama kaip elektroniniu būdu išleidžiama valiuta, kurios pakeitimas ị realios vertès pinigus nėra garantuotas valstybès. Dauguma mokslininkų kriptovaliutas apibūdina kaip virtualų turtą, kurio paskirtis yra būti mainų priemone ar terpe. Tam sukurti naudojama sudėtinga kriptografijos technologija, kuri užtikrina finansinių operacijų srauto saugumą ir papildomų kriptovaliutų generavimą (Schueffel, 2017; Chohan, 2018). Andrianto (2017) apibūdina kriptovaliutas kaip sparčiai besiplečiančią mokèjimo sistemą, priklausančią nuo skaitmeninès blokų grandinès sistemos. Dourado ir Brito (2014) įvardina virtualias valiutas kaip sistemą, kuri naudoja kriptografiją, kad užtikrintų saugų skaitmeninių žetonų pardavimą ar keitimąsi decentralizuotu būdu. Tad bendrai tariant, kriptovaliuta tai - mokejjimų terpès sistema, naudojanti kriptografijos technologiją, kad sukurtų virtualaus turto vertę.

Baur et al. (2018) kriptovaliutas apibrèžia, kaip investavimo priemonę. Mokslininkai teigia, kad virtualios valiutos nèra tik mokejjimų sistema, tačiau ir ypač sparčiai populiarèjanti investavimo priemonè. Kriptovaliutų rinka yra auganti, nestabili ir nuolat besikeičianti, kas paverčia ją ypač rizikinga. Augantis susidomèjimas investavimo srityje išbalansuoja kriptovaliutų kainas, sukeldamos vertès nepastovumą, kas atbaido potencialius valiutos naudotojus. Taip pat nevertètų užmiršti ir rizikos dèl didelès kriptovaliutų koncentracijos vienoje vietoje, ko pasèkoje galimas dirbtinis kainos sukèlimas. Paprasčiausias pavyzdys būtų sutartinis sandoris tarp dviejų santykinai didelį kiekị kriptovaliutų turinčių šalių, kur dirbtinai atliekant pirkimo ir pardavimo sandorius, skatinamas dirbtinas kainos augimas. Stabili pusiausvyra tarp investuotojų ir vartotojų yra ypač svarbi, siekiant išlaikyti kriptovaliutų, kaip mainų priemonès, matavimo mato ir kaupimo būdo sèkmę (Platanakis ir Urquhart, 2019).

Rinkos pokyčio krypties prognozavimas yra sudètingas ir tuo pat įdomus mokslininkams, siekiantiems pagerinti jau egzistuojančius prognozavimo modelius. Kiekvieno investuotojo tikslas, renkantis investavimo strategiją, remiantis modeliais, medija ir naujausia informacija, ekonomikos prognozėmis ir panašiai, yra atlikti sprendimus, kurie sumažintų riziką ir padidintų pelną. Kriptovaliutos ypač pasižymi savo kainų nepastovumu, ką virtualios valiutos ypač aiškiai įrode 2017-2018 metais (1 paveikslas). Kainos kintamumas rodo, kiek yra rizikingas turto laikymas tam tikru metu ar laikotarpius. Kuo didesnis kainos pokyčio procentas, tuo didesnè tikimybè, kad vertė gali arba smarkiai pakilti arba taip pačiai nukristi. Tai sudaro ganètinai didelę riziką, tačiau tuo pat metu padidina šansus patirti dideli pelną per trumpą laiko tarpą. Theblockcrypto.com (2019) atlikta kainų kitimo analizė parodė, kad 2009 birželi Bitcoin buvo pati nestabiliausia valiuta - kainos pokytis siekè $102 \%$. Nepaisant to, Bitcoin išliko pelningiausia kriptovaliuta, kurios verte netgi pakilo 30 \%. „Ltecoin“ kainų svyravimas siekè 98 \%, „XRP“- $82 \%$. Bitcoin kainos augimas sukèlè rinkos dalyviams vilčių, kad tai numatoma rinkos augimo kryptis. Dèl to dauguma investuotoju koncentruojasi ị kriptovaliutų rinkos augimo galimybes. Coinmarketcap.com duomenimis, dabartinėje rinkoje yra 2,895 kriptovaliutos, kurių kapitalizacija, paklausa ir cirkuliavimas rinkoje yra skirtingas. Atsižvelgiant ị tai, kad investavimo rizika yra didelè, ypač aktualus ir svarbus yra tikslingas rinkos prognozavimas.

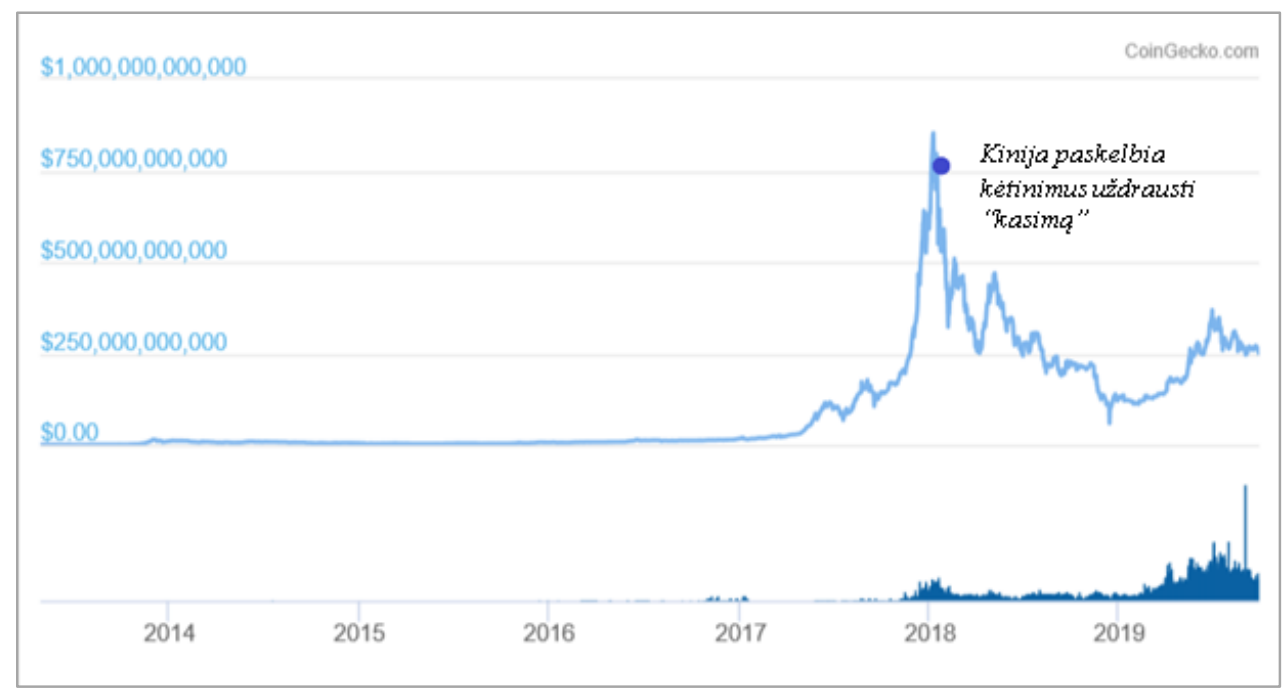

1 paveikslas. Bendra kriptovaliutų rinkos kapitalizacija (JAV doleriais) 2013-2019 metais (coingecko.com, 2019) 
Nors klasikinis sprendimų prièmimo požiūris yra grindžiamas laiko patikrintomis sprendimų prièmimo taisyklèmis, šiuolaikinis sprendimų palaikymas daugiausia grindžiamas statistiniais irodymais, kurie gaunami analizuojant patikimus duomenis (Feuerriegel ir Fehrer, 2016). Ši duomenų pagrịstumu palaikomą sprendimu prièmimo būdą paskatino suvokimas, kad žmonès ir jų kompiuteriai generuoja daug ir ịvairių duomenų, kuriuos yra i̇manoma analizuoti. Šis atotrūkis ir bandymas fiksuoti ir naudoti pusiau struktūruotų ir nestruktūruotų duomenų vadinamas „Big Data“ - didžiųjų duomenų era. Terminas apima nuolat didejjančių duomenų kiekį ir sparčiai besivystančios kompiuterinès technikos tobulinimą, kad sprendimų prièmimas būtų grindžiamas sudėtingų duomenų analize (Power, 2014). Tikslingam, greitam ir efektyviam gaunamos informacijos analizavimui pasitelkiami algoritmai. Mašininio mokymosi procese, sudarytam algoritmui duodamas duomenu rinkinys, kurio pagrindu atliekamos prognozès ar sprendimai (Mahdavifa ir Ghorbani, 2019). Gilusis mokymasis yra mašininio mokymosi atšaka, kuriame mokymasis yra sudarytas iš neuronų sluoksnių, kurių kiekvienas pateikia mokymosi proceso algoritmą. Neuronų sluoksniai leidžia palaipsniui išgauti savybes, būdingas kiekvienam lygiui iš pateiktų tyrimo duomenų. Giliojo mokymosi algoritmas sudaro struktūrą, kuri veikia atgaline seka, kurios metu kiekviename sluoksnyje gauti parametrai yra pritaikomi prieš tai gautiems parametrams, tam, kad būtų sudaryta visus sluoksnius atspindinti veiksmų struktūra (Zhong et al., 2018; Aldweesh et al., 2019).

Kaip ir akcijų rinkos prognozavime, taip ir kriptovaliutų rinkoje, kyla klausimas - ar yra ịmanoma nuspėti kriptovaliutų elgesị, kai šis yra toks dinamiškas, kas iš esmès prieštarauja Efektyvios rinkos hipotezei, pagal kurią kainų kitimas yra atsitiktinis (Sun et al., 2020). Ankstesni tyrimai virtualių valiutų kainas numatè dviem būdais: empirine analize ir mašinų mokymosi algoritmų analize. Šiame straipsnyje apžvelgiama giliojo mokymosi algoritmų metodų taikymas literatūroje, kriptovaliutų kainų prognozavimui.

Sun et al. (2020) atliko kainų prognozavimą taikydami tris skirtingus metodus: „LightGBM“, SVM (,Support Vector Machines“) ir RF („Random Forests“). Tyrimui buvo naudojamos 42 kriptovaliutos, pasirinktos pagal aktyvumą. Gauti rezultatai parodè, kad modeliai geriausiai veikia naudojant dviejų savaičiu prognozavimo laikotarpi. Atlikus tą patị tyrimą pasirinkus 10 stipriausių valiutų, prognozavimas buvo šiek tiek tikslesnis. To pasèkoje autoriai prièjo išvada, kad prognozavimo tikslumas koreliuoja su kriptovaliutų stiprumu ir prognozavimo laikotarpiu. Lyginant tris modelius, LightGBM parode geresnius rezultatus lyginant su likusiais dviem.

Lahmiri ir Bekiros (2019) kriptovaliutų kainų prognozavimui pasirinko siauresnę imtį - tris pačias aktyviausias kriptovaliutas - Bitcoin, Digital Cash ir Ripple. Taikant giliojo mokymosi algoritmus. Šiuo tikslu buvo pasirinkti du algoritmai - LSTM ir apibendrintas regresinis tinklas (angl. generalized regression neural networks, toliau GRNN). Autoriai taip pat šiek tiek patobulino LTSM modeli, pertaikydami jam "kontroliuojančius vartus“, kurių galutinis tikslas - filtruoti informaciją, kuri yra reikšminga, ir galiausiai taptų prognoze. Tyrimo rezultatai parodé, kad LSTM giliojo mokymosi sistema, geriau sugebejjo išmokti trijų pasirinktų valiutų kitimo dinamiką ir pateikti tikslesnei prognozes, lyginant su GRNN. Autoriai taip pat pabrèžè, kad giliojo mokymosi sistemos sugeba ịsisavinti tiek trumpalaikę tiek ilgalaikę informaciją tuo pat metu, kas suteikia pranašumo siekiant atskleisti kitimo seką.

Madan et al. (2015) taip pat taikè giliojo mokymosi algoritmus Bitcoin kainų prognozavimui. Bendrai duomenų kitimo tendencija aptikti, taikytas atraminių vektorių klasifikatoriaus (SVM) algoritmas. Tyrimo rezultatai buvo teigiami - autorių algoritmas 98,7 \% tikslumu numatė Bitcoin dienos kainas, ir 50-55 \% aukšto dažnio kainas. Bitcoin kainą taip pat prognozavo ir Chen et al. (2020). Autoriai naudojo tiek statistinius metodus tiek mašininio mokymosi metodus. Dienos kainos prognozavime, statistiniai metodai pasiekè $66 \%$ tikslumą, kur giliojo mokymosi algoritmų rezultatai pasieke $65 \%$ tikslumą. Tačiau lyginant su aukšto dažnio kainų prognozavimu, mokymosi modelių rezultatai pasiekusi $67,2 \%$ tikslumą, kai statistinio prognozavimo tikslumo vidurkis siekè - $53 \%$. Rebane et al. (2018), Torres ir Qiu (2018) savo darbuose, taip pat lygino giliojo mokymosi prognozavimo rezultatus su laiko eilučių analizès modelio rezultatais. Abu darbai patvirtino, kad algoritmo pateiktos prognozès yra tikslesnės negu laiko eilučių statistinio prognozavimo metodo.

Kim et al. (2016) kriptovaliutų kainos vertinimui naudojo virtualių valiutų svetainių naudotojų išreiškiamus komentarus taikant sentimentų analizę, kaip veikianti jų kainos svyravimo ir naudojimo faktorių. Mokslininkai pritaikè ši paprastą, tačiau efektyvų būdą trijų populiariausių kriptovaliutų kainų ir operacijų prognozavimui. Autoriams pavyko pasiekti 79,57 \% prognozavimo tikslumą taikant Granger priežastingumo modelį. Tyrimas parodè, kad tiek kainų kitimas, tiek operacijų apimtis yra stipriai susiję su teigiamomis temomis, komentarais bei atsakymais. Mai et al. (2018) atliko tyrimą apie Bitcoin kainos kitimo ir socialinių tinklų sąsają. Šis tyrimas parodè, kad socialiniuose tinklai sudaryti iš $95 \%$ pasyvių naudotojų, kas palieka $5 \%$ aktyvių vartotojų, kurie paskelbia didžiają dalị komentarų ir diskusijų, veikiančių kriptovaliutų kainų svyravimus. Tyrimo rezultatai leido prieiti išvadą, kad sentimentų analizė yra svarbus ir efektyvus kriptovaliutų kainų prognozavimo būdas.

Apžvelgus šiuos ir panašius empirinius tyrimus, pastebėta, kad tyrimui naudojant dažną kainos kitimą, giliojo mokymosi algoritmų rezultatai yra tikslesni. Kai kurie mokslininkų darbai parodè, kad taikant statistinius metodus prognozavimui, galimi netgi tikslesni rezultatai. Žinoma, rezultatų gavimui yra ypač svarbus duomenų dažnumo pasirinkimas, dèl ypač greitai kintančios kriptovaliutų kainos bei prognozavimo laikotarpio pasirinkimas. Nepaisant to, galima pabrěžti, kad dirbant su dideliu kiekiu duomenų, dirbtinis intelektas yra pranašesnis, mat duomenys apdorojami su mažesniu žmogiškųjų klaidų faktoriumi. 


\section{Giliojo mokymosi algoritmai kriptovaliutu prognozavime}

Kaip jau minèta, gilusis mokymasis yra mašininio mokymosi atšaka. Šis algoritmas buvo sukurtas remiantis žmogaus biologine smegenų struktūra ir jos neuroninio tinklo funkcijomis. Neuronų tinklas yra programavimo sistema, sudaryta iš sujungtų neuronų, kuriais yra perduodami signalai. Ši sistema leidžia kompiuteriui mokytis iš stebejjimo duomenų, taip palaipsniui tobulindama veiksmų atlikimą signalų perdavimo metu (Talo et al., 2019). Vieno neurono signalo išvestis (angl. output) veikia kaip kito neurono ịvestis (angl. input). Algoritmo veikimo principas yra daugkartiniu informacijos apdorojimu, kas suteikia gilesnị ir naudingesnị mokymąsi. Neuronų tinklai dažniausiai yra sudaryti iš sluoksnių, kurių kiekvieną sudaro daugybe neuronų. Tokia struktūra leidžia kompiuteriui rinkti apdorotus duomenis, kurie moko, kaip turètų būti pakeisti vidiniai parametrai, kad būtų atvaizduotas kiekvieno sluoksnio rezultatas. Rezultatai ar atpažinti pasikartojantys veiksmai yra skaitiniai ir išreikšti vektoriuose, kurie vartotojui pateikiami kaip vaizdai, tekstas, laiko eilutès ir pan. (Zhong et al., 2018).

Sluoksniai yra surišti mazgais (sinapsėmis), kuriuose vyksta skaičiavimai. Mazgas derina duomenų ịvestị su koeficientų arba svorių rinkiniu, kurie tą ịvestị arba sustiprina, arba sumažina, taip priskirdami ịvesties reikšmę užduočiai, kurią bando išmokti algoritmas. Sinapsių ir neuronų sandaugų suma sudaro aktyvavimo funkciją, kuri apriboja neurono išvesties amplitudę. Naudojant aktyvavimo funkciją yra nustatoma, ar ir kokiu mastu išvesties signalas toliau turètų būti siunčiamas per tinklą. Jei signalas praeina, neuronas tampa ,aktyvuotas“(Selman, 2012; Mahdavifar ir Ghorbani, 2019). 2 paveikslas vaizduoja neurono tinklo veiklos struktūrą.

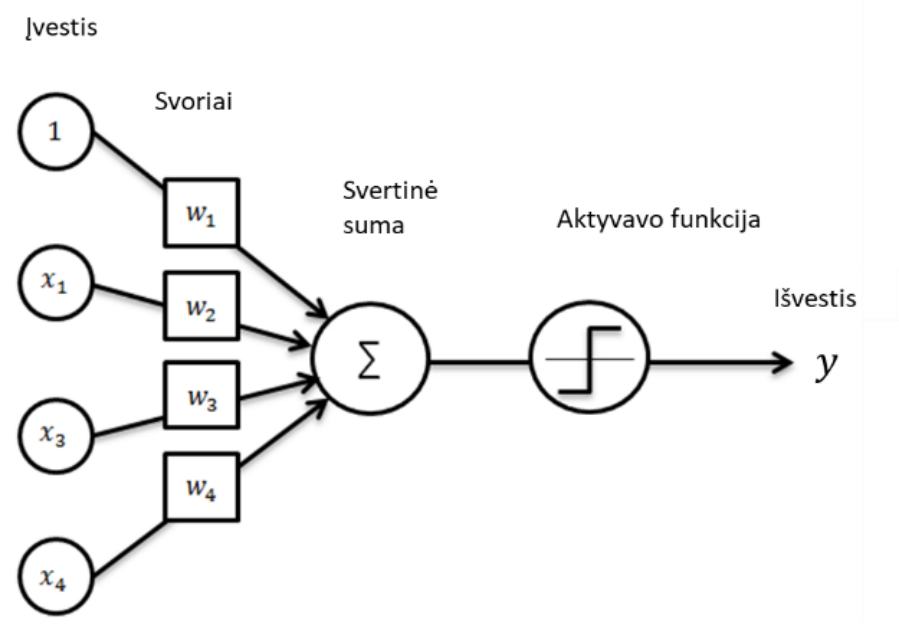

2 paveikslas. Neurono tinklo veiklos struktūra (Love, 2007)

Visų pirma yra sudedamos neuronų reikšmės, kurios buvo prieš tai prijungtuose stulpeliuose. Paveiksle vaizduojami keturi signalai $\left(\mathrm{X}_{1}, \mathrm{X}_{2}, \mathrm{X}_{3}, \mathrm{X}_{4}\right)$, taigi turime keturis neuronus besijungiančius prie vieno. Kiekvienas signalas yra sudauginamas iš atitinkamo svorio $\left(\mathrm{w}_{1}, \mathrm{w}_{2}, \mathrm{w}_{3}, \mathrm{w}_{4}\right)$. Kiekviena neuronų jungtis turi savo svorius reikšmes, kurios yra vienintelès kintančios mokymosi proceso metu. Trečiu žingsniu yra gaunama sandaugų suma. Suma keliauja į aktyvacijos funkciją, kuri dažniausiai yra pakeičiama į reikšmę nuo 0 iki 1 . Tam dažniausiai naudojama Sigmoido funkcija, dar vadinama logistine funkcija (3 paveikslas). Gauta reikšmé, siunčiama toliau, kaip signalas kitam neuronui (Selman, 2012; Mahdavifar ir Ghorbani, 2019). Pagrindine neuronų tinklo užduotis yra sugeneruoti išvesties rezultatą kiekvienam signalui. Iš pradžiu algoritmas bando nustatyti ir suderinti teisingų atsakymų skaičių, taip kartais tiesiog atspejjant atsakymus. Spèjimai lyginami su realiai duomenimis, pagal ką keičiami parametrai, kol gaunamas rezultatas, taptu panašesnis i pateiktus „tikruosius“ duomenis. Taigi, kol algoritmas „mokosi“ jis tūkstančius kartų spèlioja, lygina, priskiria svorius ir vèl lygina rezultatus, kol spèlionès nustoja tikslèti arba tikslumas tampa per mažas tolesniam tikslinimui (Tang et al., 2018).

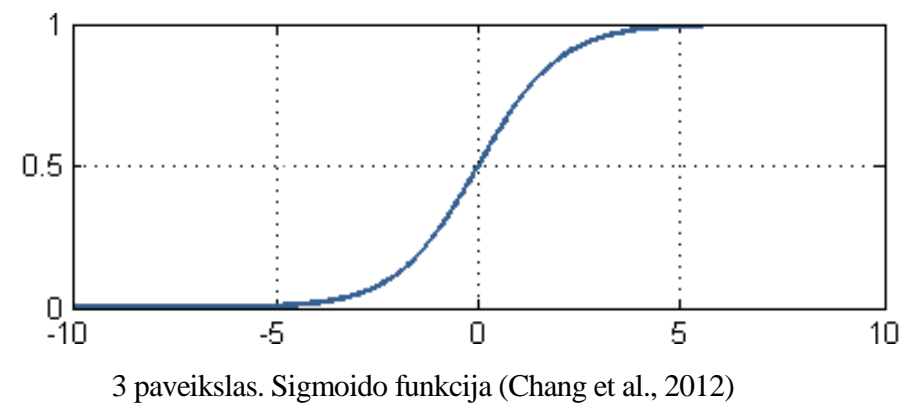


Pagrindinis giliojo mokymosi skiriasis bruožas nuo kitų mašininio mokymosi metodų yra, tai, kad giliojo mokymosi algoritmas klasifikuoja ir mokosi daugiau pagal sutapimus ir tam tikrus aptinkamus duomenų bruožus, negu specifinių užduočių algoritmus. Tai yra naudinga kriptovaliutų prognozavimui, kai pateikus didelị duomenų kieki, algoritmas surenka panašius kainų pokyčius. Taip pat algoritmo klasifikatoriai mokosi su ịvairiu duomenų kiekiu, kurio rezultato tikslumas gerèja didėjant duomenų kiekiui (4 paveikslas) (Tang et al., 2018).

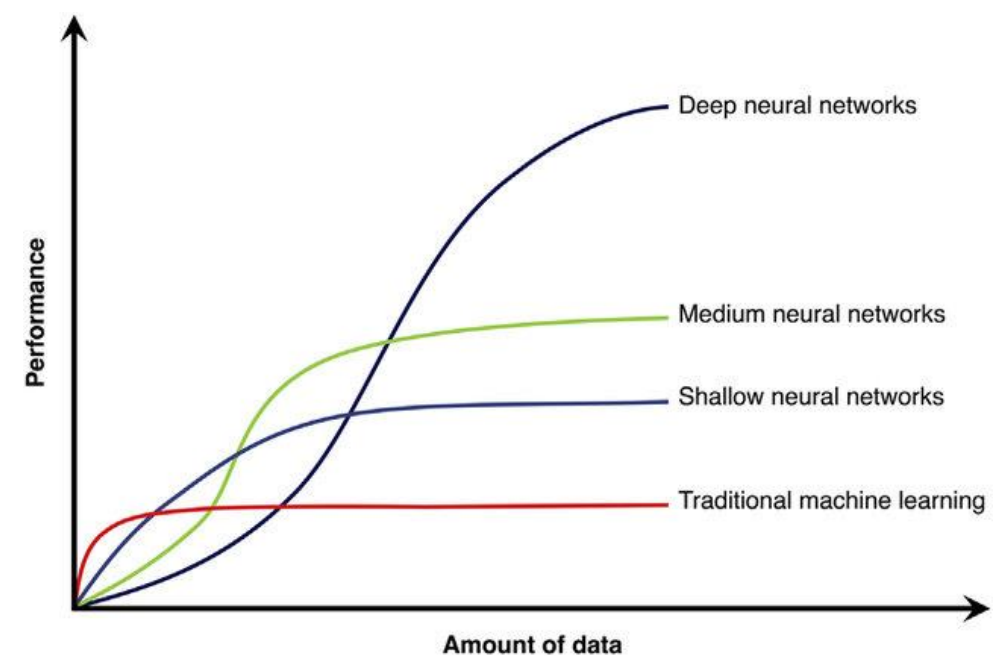

4 paveikslas. Duomenų kiekio įtaka dirbtinio intelekto metodų rezultatų tikslumui (Tang et al., 2018)

Ilgalaikès trumpalaikès atminties tinklas (LSTM) yra besikartojančių neuronų tinklo (angl. recurrent neural network, toliau RNN) algoritmo tęsinys (Hochreiter ir Schmidhuber, 1997). RNN algoritmas geba aptikti stebimų duomenų sekas ir jas tiksliai suklasifikuoti pagal koreliacijos stiprumą. Siekiant pašalinti RNN algoritmo netikslumus besimokant iš laiko-eilučių duomenų, buvo sukurta patobulinta jo versija, kuri geba apdoroti ir mokytis iš ilgesnių laiko eilučių - LSTM (Nakisa et al., 2018). Būtent dèl šios priežasties LSTM yra tinkamas metodas kriptovaliutų kainų prognozavimui. Straipsnio tikslui pasiekti bus taikomas sekos eilès mokymosi regresinis modelis (angl. sequence-to-sequence learning). Šiame ilgalaikès trumpalaikès atminties modelio mokymo būde gauti atsakymai yra mokymosi seka, kurios reikšmès keičiasi per vieną periodą. To pasėkoje, kiekvienos įvesties laiko žingsnyje, LSTM tinklas mokosi numatyti kito laiko žingsnio reikšmę.

Taikant ši prognozavimo metodą, LSTM algoritmas mokosi prognozuoti. Tam kad būtų vykdomi žemiau pateikti modelio mokymosi žingsniai (5 paveikslas) taikomas algoritmo kodas:

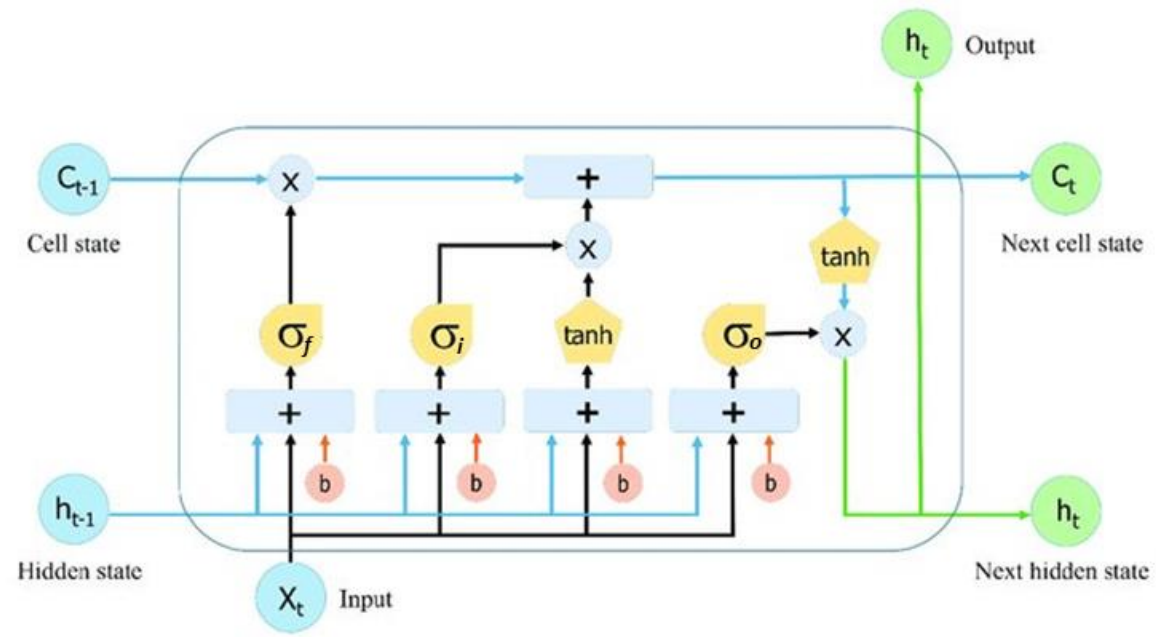

5 paveikslas. Ilgalaikès trumpalaikès atminties neuronų tinklo struktūra (Le et al., 2019)

LSTM tinklas yra sudarytas iš atminties blokų, kurie vadinami ląstelèmis (angl. cells). Duomenų srauto judejjimą sudaro būsenų perdavimas iš vienos ląstelès ị kitą: ląstelès būsenos (Ct-1 ), kuri siunčia paskutinio LSTM vieneto atminties informaciją ir paslèptos būsenos (ht-1) - paskutinė LSTM vieneto išvesties. Paslèptoji būsena veikia, kaip neuronų tinklo atmintis - saugo informaciją iš apdorotų duomenų prieš tai. Ši būsena gaunama sudarant vektorių iš esamos ir buvusių ịvesčių, taip saugant informaciją apie ne tik esamą bet ir visas buvusias ịvestis. Vektorius toliau 
keliauja per aktyvacijos funkciją $(\sigma)$, kurios gautas rezultatas yra nauja paslèpta būsena (ht), kuri toliau keliauja link naujos icvesties (Xt) (Le et al., 2019).

Duomenys iš ląstelès gali būti pašalinti arba pridèti per sigmoido vartus, kartais dar vadinamus reguliatoriais (angl. sigmoid gate). Vartai yra sudaryti iš svorių. LSTM dažniausiai turi tris vartus: įvesties( $\sigma i)$, išvesties( $\sigma 0)$ ir pamiršimo ( $\sigma f)$. Jų paskirtis yra skirstyti ir reguliuoti duomenų srautus. Išvesties vartai atskiria, kuri informacija turètų būti palikta, o kuri išmesta. Čia, jei iš sigmoido funkcijos gauta reikšmė yra arti 0 , vadinasi, turi būti pamiršta, jei, kuo arčiau 1 - išsaugota. İvesties vartai skirti ląstelès būsenos atnaujinimui. Čia pirmiausia paskutinè paslèpta būsena ir nauja ịvesties suma yra paverčiami ị reikšmę, nuo 0 iki 1, naudojant sigmoido funkciją. Suma neuroniniais tinklais keliauja ir ị tanth funkciją, kur priskiriama reikšmė nuo -1 iki 1, tam kad tinklas būtų sureguliuotas. Abiejų funkcijų išskirtys yra sudauginamos ir keliauja į sigmoido funkciją, kur vèl yra sprendžiama ar rezultatas turètų būti atsimintas ar pamirštas. Apdorota informacija keliauja link prieš tai buvusios ląstelès būsenos (Ct-1), kurios reikšmè yra sudauginama su pamiršimo vartų išvestimi. Gauta sandauga yra susumuojama su įvesties ir tanth funkcijų sandauga. Ši išvestis keliauja toliau, kaip atnaujinta ląstelès funkcija - Ct (Tran et al., 2018).

Išvesties vartai skirti paslèptos ląstelès būsenos atnaujinimui. Tam prieš tai esanti paslèpta ląstelès būsenos reikšmè siunčiama ị sigmoido funkciją, kartu su nauja įvestimi. Tuomet gauta reikšmė sudauginama su reikšme gauta siunčiant atnaujintą ląstelę $(\mathrm{Ca})$ it tanth funkciją. Sandauga yra nauja paslèpta išvestis $\left(\mathrm{h}_{\mathrm{t}}\right)$. Apibendrinant, vartai mokosi, kuriuos duomenis reikia palikti, kuriuos išmokti ir saugoti. Tokiu būdu informacija perduodama ilgoje sekų grandinèje (Tran et al., 2018).

Tyrimo praktinèje dalyje ilgalaikès trumpalaikès atminties modelio algoritmas mokomas prognozuoti kriptovaliutos kainą. Tyrimui buvo pasirinktos penkios kriptovaliutos, pagal jų kapitalizaciją rinkoje, remiantis naujausiais coinmarketcap.com duomenimis: Bitcoin, XRP, Bitcoin Cash, Litecoin, Binance Coin. Algoritmo mokymui yra pasirinktas kasdieninis uždarymo kainos kitimas periodui nuo 2017 m. sausio 1 iki 2019 m. spalio 31. Duomenys surinkti iš finance.yahoo.com atviros prieigos svetainès. Žemiau pateikti, duomenų prognozavimo žingsniai:

- Algoritmas mokosi nuspèti reikšmes naudojant prieš tai buvusią laiko eilutès reikšmę iš eilès pagal seką, taip paslenkant kiekvieną buvusią vertę per vieną laiko žingsnį. Mokymuisi bus testuojama ir mokomasi iš $90 \%$ pateiktų duomenų, likusius $10 \%$ prognozuojant ir vertinant nuokrypi nuo gautų reikšmių ir realių duomenų.

- Kad algoritmo mokymasis būtų tikslesnis ir neiškryptų, duomenys standartizuojami, taip kad vidurkio ir vieneto dispersija būtų lygi nuliui. Duomenų prognozavimui bus naudojami tokie patys parametrai, kaip ir treniruočių duomenims.

- Domenų prognozavimui algoritmas mokomas su kiekviena nauja ịvestimi numatyti būsimą reikšmę. Taigi algoritmas mokysis iš numatytų reikšmių sekos principu.

- Numatytos reikšmès lyginamos su mokymosi duomenimis skaičiuojant kvadratų vidurkio kvadratinės šaknies nuokrypi (angl. root mean square error, toliau RMSE).

- Naudojant realius duomenis, LSTM tinklas bus atnaujintas, tam kad prognozuojant sekančią laiko žingsnio reikšmę, būtų naudojami realūs duomenys, vietoj prieš tai išprognozuoto.

- Vertinamas prognozavimo tikslumas, skaičiuojant kvadratų vidurkio kvadratinès šaknies nuokrypis ir vidutinè absoliutinè procentinè paklaida su atnaujintai duomenimis.

\section{Giliojo mokymosi algoritmo taikymo kriptovaliutų kainų prognozavimui tyrimas}

Tyrimas atliekamas naudojant Matlab programinę terpę, kuri yra skirta įvairiems matematiniams veiksmams atlikti, vienos iš jų - operacijos matricomis. Ši programa pasirinkta dẻl savo neuroninių tinklų funkcijų rinkinio, kuris skirtas neuroninių tinklų kūrimui. Tyrimo metu visiems duomenims naudojami vienodi parametrai. Kad duomenys mokymosi proceso metu neiškryptų ir būtų tinkami neuronų tinklo formavimui, nustatomi nulio vidurkio ir vieneto dispersijos standartizavimo rèmai. Kadangi duomenų kiekis didelis, nustatoma, kad LSTM sluoksnis turès 200 paslèptujų jungčių. Prognozavimas vyks sekos principu, tam algoritme nurodama, kad mokymasis vyktų iš išvesties, t. y. su kiekvieną ịvestimi, LSTM numatys sekantị žingsni, jo atsakymas bus naudojamas kito žingsnio numatymui ir t. t. dèl ko mokymasis neturi galutinès mokymosi įvesties. Tam, kad prognozavimas būtų tikslus, duomenų atnaujinimui nurodoma 300 epochų. Šios epochos reprezentuoja, kiek kartų visi mokymo vektoriai bus naudojami svorių atnaujinimui. Šiame etape $90 \%$ testuojamų duomenų yra naudojami mokymuisi prieš svorių atnaujinimą.

Lentelè 1 pateikia testuojamų kriptovaliutų atnaujinto neuronų tinklo prognozavimo kvadratų vidurkio kvadratinès šaknies nuokrypi prognozuotam laikotarpiui ir vidutinè absoliutinè procentinè paklaida (angl. mean absolute percentage error, toliau MAPE) pirmai prognozès savaitei. Čia MAPE reprezentuoja prognozavimo tikslumą - paklaidos dydį procentais nuo tikrųų reikšmių, RMSE parodo nuokrypių sklaidą, tad kuo didesnis RMSE, tuo didesni prognozių nuokrypiai nuo realių reikšmių. 
1 lentelè. Prognozavimo su atnaujintai duomenimis nuokrypiai (sudaryta autorių)

\begin{tabular}{|c|c|c|c|c|c|}
\hline & Bitcoin & XRP & Bitcoin Cash & Litecoin & Binance Coin \\
\hline RMSE & 459,68 & 0,0097 & 13,11 & 2,9338 & 1,96 \\
\hline MAPE & $0,813 \%$ & $0,027 \%$ & $0,033 \%$ & $0,024 \%$ & $0,027 \%$ \\
\hline
\end{tabular}

Iš 1 lentelès matome, kad didžiausias tiek RMSE tiek MAPE nuokrypis yra Bitcoin kriptovaliutos duomenims. Tai galimai yra dèl to, kad tai pati nepastoviausia kriptovaliuta, turinti didžiausią kapitalizaciją ir investuotojų susidomėjimą, kas lemia akivaizdžią RMSE reikšmės atotrūkį, nuo likusių rezultatų. Kadangi Bitcoin kainos pokyčiai taip pat jautresni tiek ekonomikos svyravimams, tiek socialinėse erdvėse vyraujantiems vartotojų lūkesčiams, algoritmui yra sunkiau mokytis ir tiksliau prognozuoti kainos pokyčius, ko pasėkoje nuokrypis yra didžiausias. Tačiau žvelgiant i 6 paveikslą, matome, kad kainos kitimo tendencija atitinka realius duomenis. Iš prognozės grafiko, pastebima, kad modelio prognozès pateikè žemesnes, negu realiais kainas.

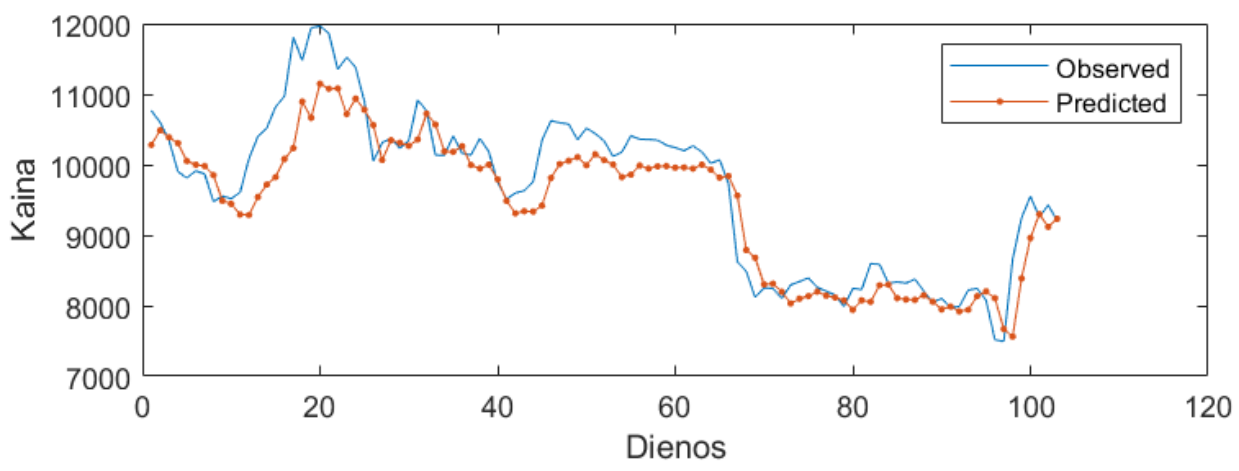

6 paveikslas. LSTM prognozės su atnaujintai duomenimis Bitcoin kriptovaliutai (sudaryta autorių)

Žvelgiant ị tiksliausias prognozes, čia galima išskirti dvi kriptovaliutas - Ripple (XRP), turintị mažiausią RMSE ir Litecoin, su mažiausiu MAPE. 7 paveikslas vaizduoja XRP kriptovaliutos prognozes su atnaujintais duomenimis. Visų pirma pastebima, kad kainos kitimo tendencija yra tarsi pasislinkusi per vieną laiko žingsnį. Taip pat iš paklaidos sklaidos matome, kad ji yra tolygiai pasiskirsčiusi, vadinasi prognozuojama kaina buvo svyruojanti - tiek didesnè, tiek mažesnè negu realūs duomenys. Stebina, tai, kad modelis išprognozavo ganètinai staigų kainos šuolį ir kritimą 60-70 dienomis, tiek visą kainos kitimo tendenciją. Tam įtakos gali turèti žemesnè kriptovaliutos kaina, ko pasėkoje gaunama mažesnè paklaidos sklaida.

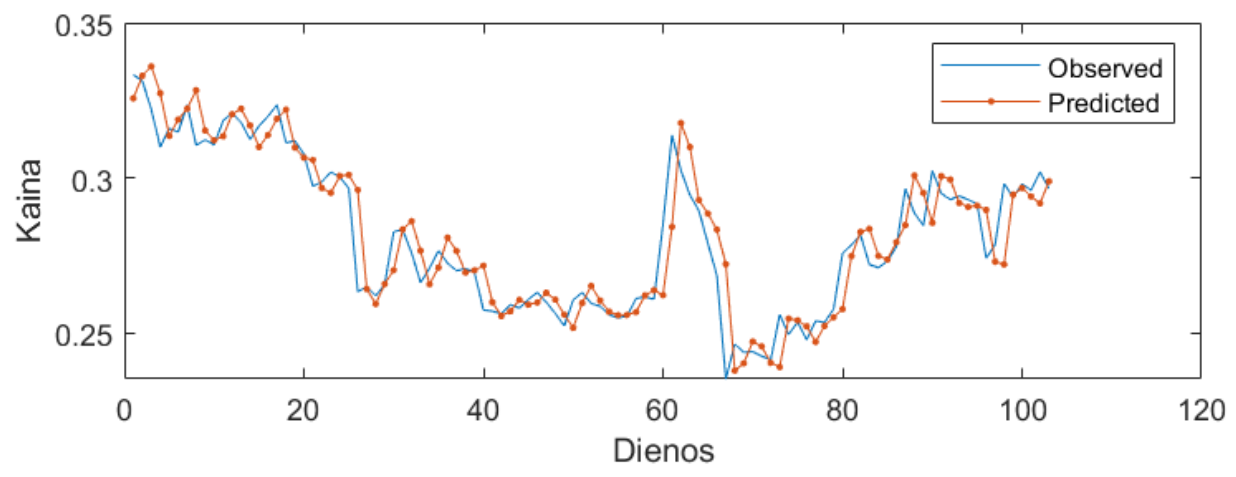

7 paveikslas. LSTM prognozès su atnaujintai duomenimis XRP kriptovaliutai (sudaryta autorių)

Žvelgiant ị Litecoin prognozių rezultatus 8 paveiksle, taip pat yra matomas tikslus realių duomenų atkartojimas, tiek ties kainos dydžiu, tiek pačia kainos kitimo tendenciją. Besimokydamas iš Litecoint duomenų, algoritmas tiksliau išpranašavo, kainos dydžius, negu XRP kriptovaliutai, tai pastebima ne vien tik iš MAPE geresnio rezultato, bet ir iš to, kad prognozuojama linija yra šiek tiek labiau „užlipus“، ant stebimų duomenų. 


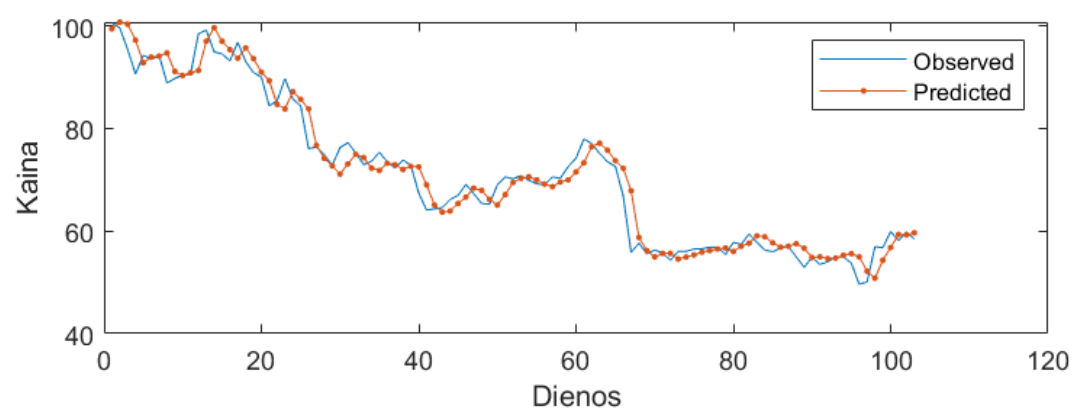

8 paveikslas. LSTM prognozės su atnaujintai duomenimis Litecoin kriptovaliutai (sudaryta autorių)

Iš 1 lentelès matome, kad Binance Coint turi mažiausią RMSE nuokrypi po XRP kriptovaliutos bei tik 0,003\% didesni MAPE nuo mažiausio rezultato. Tačiau iš 9 paveikslo matome, kad prognozuojamų duomenų atotrūkis pastebimai didesnis ir beveik visą prognozuojamą laikotarpi laikosi aukščiau realių kainų, lyginant su kitomis prognozèmis.

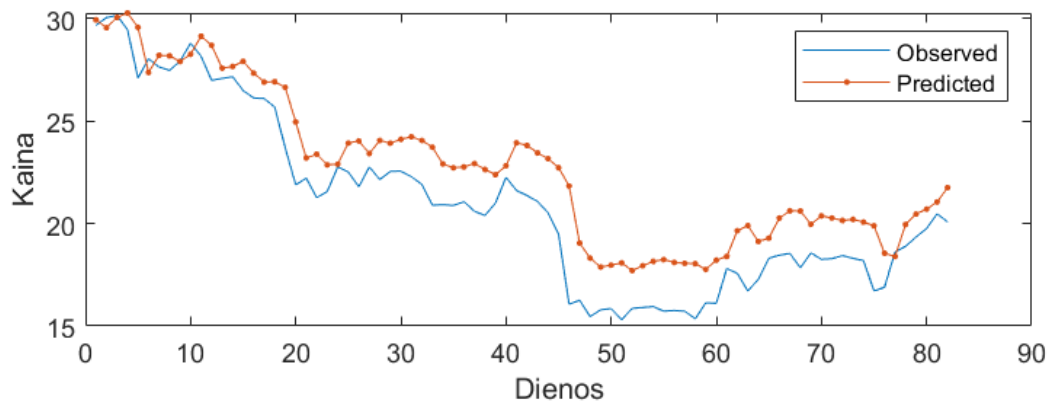

9 paveikslas. LSTM prognozės su atnaujintai duomenimis Binance Coin kriptovaliutai (sudaryta autorių)

10 paveiksle vaizduojama antra pagal nuokrypi netiksliausiai išprognozuotos kriptovaliutos - Bitcoin Cash vertès raida. Prognozės atrodo netgi tikslesnè už Litecoin, tačiau RMSE yra didesnis. Tam įtakos turi kainų skirtumai, mat lyginant pagal MAPE santykinị nuokrypị, Bitcoin Cash rezultatai yra tik 0,03\%.

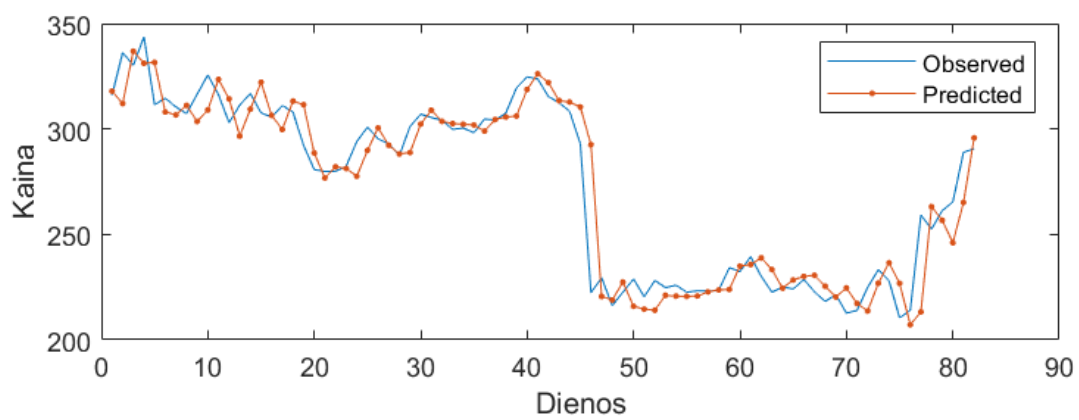

10 paveikslas. LSTM prognozės su atnaujintai duomenimis Bitcoin Cash kriptovaliutai (sudaryta autorių)

Apibendrinant galima teigti, kad LSTM modelis tiksliai atvaizduoja kainos kitimo tendenciją. Pastebima, kad mažesnės kainos kriptovaliutų prognozės yra tikslesnès ir su mažesne paklaida. LSTM modelis visoms penkioms kriptovaliutoms prognozavo realius duomenis atitinkančias kainų kitimo tendencijas. Nors giliojo mokymosi algoritmas neatkartoja tiksliai būsimų kainų prognozių, nuokrypis yra sąlyginai mažas - neperkopia $0,8 \%$ didžiausią kapitalizaciją turinčiomis kriptovaliutoms. Tokie rezultatai leidžia prognozuoti, kad dirbtinio intelekto technologijos bus sparčiai integruojamos i finansu rinką, taip plečiant finansinių paslaugų šakas elektroninèje erdvejje tiek privatiems asmenims, tiek įmonėms. Kriptovaliutų perdavimo ir vertės kitimo stebejjimo bei investavimo raliu laiku poreikis stimuliuoja paklausą ir galimybes fintech produktams, kurie leistų vartotojui saugiai, greitai ir patogiai dalyvauti kriptovaliutų rinkoje bei integruoti kriptografijos bei giliojo mokymosi technologijas ị verslo modelius. 


\section{Išvados}

Dauguma mokslininkų kriptovaliutas apibūdina kaip virtualų turtą, kurio paskirtis yra būti mainų priemone ar terpe, kur reguliacinès įstaigos kriptovaliutas mato, kaip nereguliuojamą virtualią vertės išraišką, kuri gali būti naudojama, kaip pinigų alternatyva bei investavimo priemonè. Užtikrintumo ir saugumo poreikis, skatina turèti mechanizmą ar prognozavimo modelį, kuris tai atliktų už juos ir garantuotų pelną su mažiausia rizika.

Mokslinès literatūros apžvalgos parodé, kad yra keli dirbinio intelekto naudojimo modeliai, kurie gali būti pritaikyti kriptovaliutų kainų ir operacijų prognozavime. Vieni iš dažniausiai naudojamų modelių buvo LTSM ir Random Forest. Tyrimui pasirinktas ilgalaikès trumpalaikès atminties tinklo algoritmas, dèl laiko-eilučių duomenu apdorojimo pritaikomumo. Gauti rezultatai parodè, kad prognozių paklaida yra didesnè kriptovaliutoms, turinčioms istoriškai didesnị kainos svyravimą, lyginant su stabilesnèmis, žemesnę kainą turinčios kriptovaliutomis. Nepaisant to, vidutinè absoliutinè procentinè paklaida analizuotoms kriptovaliutoms neviršijo $0,8 \%$, ką galima laikyti geru prognozavimo rezultatu. Taigi galima teigti, kad LSTM modelis yra tinkamas kriptovaliutu kainų prognozavimui. Remiantis šiais rezultatais, giliojo mokymosi algoritmų bei kriptografijos technologija gali būti pritaikyta sudarant optimalius investicinius portfelius bei jų rizikos valdyme. Šių technologijų pritaikymas finansų rinkoje užtikrintų finansinių pavedimų saugumą, greitị ir anonimiškumą. Plečiantis kriptovaliutų primitinimui ir dvipusiškumui, auga fintech paslaugų paklausa bei reguliacinè reikmè, užtikrinanti finansini makroekonomikos stabilumą. Visos šios technologinès galimybès kelią gilesnio tyrimo reikalaujančią problemą: kaip išlaikyti finansinị stabilumą, kai finansų dalyviai vis labiau remiasi kompiuterio sprendimais bei renkasi necentralizuotas ir nereguliuojamas investavimo priemones. Tai verčia hipnotizuoti, kas bus jei visi finansų rinkos dalyviai žinos kaip uždirbti su maža rizika? Apibendrinant, giliojo mokymosi algoritmų pritaikymas investavimo procese, tiek pačios kriptovaliutų rinkos vystymasis rodydamas daug potencialo, neslepia ir galimų rizikų.

\section{Literatūra}

Aldweesh, A., Derhab, A., \& Emam, A. Z. (2019). Deep learning approaches for anomaly-based intrusion detection systems: A survey, taxonomy, and open issues. Knowledge-Based Systems, 189, 105124. https://doi.org/10.1016/j.knosys.2019.105124

Andrianto, Y. (2017). The effect of Cryptocurrency on investment portfolio effectiveness. Journal of Finance and Accounting, 5(6), 229-238. https://doi.org/10.11648/j.jfa.20170506.14

Baur, D. G., Hong, K. H., \& Lee, A. D. (2018). Bitcoin: Medium of exchange or speculative assets? Journal of International Financial Markets, Institutions and Money, 54, 177-189. https://doi.org/10.1016/j.intfin.2017.12.004

Chang, J., Arbeláez, P., Switz, N., Reber, C., Tapley, A., Davis, J. L., Cattamanchi, A., Fletcher, D., \& Malik, J. (2012). Automated tuberculosis diagnosis using fluorescence images from a mobile microscope. In N. Ayache, H. Delingette, P. Golland, \& K. Mori (Eds.), Medical Image Computing and Computer-Assisted Intervention - MICCAI 2012. (Lecture Notes in Computer Science, Vol. 7512). Springer. https://doi.org/10.1007/978-3-642-33454-2_43

Chen, Z., Li, C., \& Sun, W. (2020). Bitcoin price prediction using machine learning: An approach to sample dimension engineering. Journal of Computational and Applied Mathematics, 365, 112395. https://doi.org/10.1016/j.cam.2019.112395

Chohan, U. (2018). Cryptocurrencies: A brief thematic review. SSRN Electronic Journal. https://doi.org/10.2139/ssrn.3024330

Dourado, E., \& Brito, J. (2014). Cryptocurrency. The New Palgrave Dictionary of Economics, 50(1), 1-10. https://doi.org/10.1016/j.jempfin.2018.11.002

Feuerriegel, S., \& Fehrer, R. (2016). Improving decision analytics with deep learning: The case of financial disclosures. Paper presented at the $24^{\text {th }}$ European Conference on Information Systems, ECIS 2016.

Hochreiter, S., \& Schmidhuber, J. (1997). Long short-term memory. Neural Computation, 9(8), $1735-1780$. https://doi.org/10.1162/neco.1997.9.8.1735

Kim, Y. B., Kim, J. G., Kim, W., Im, J. H., Kim, T. H., Kang, S. J., \& Kim, C. H. (2016). Predicting fluctuations in cryptocurrency transactions based on user comments and replies. PLOS ONE, 11(8), 0161197. https://doi.org/10.1371/journal.pone.0161197

Lahmiri, S., \& Bekiros, S. (2019). Cryptocurrency forecasting with deep learning chaotic neural networks. Chaos, Solitons and Fractals, 118, 35-40. https://doi.org/10.1016/j.chaos.2018.11.014

Le, X. H., Ho, H. V., Lee, G., \& Jung, S. (2019). Application of Long Short-Term Memory (LSTM) neural network for flood forecasting. Water (Switzerland), 11(7). https://doi.org/10.3390/w11071387

Lietuvos Bankas. (2017). Lietuvos bankas skelbia pozicija dèl virtualiuju valiutu. https://www.lb.lt/lt/naujienos/lietuvosbankas-skelbia-pozicija-del-virtualiuju-valiutu

Lietuvos Respublikos Seimas. (2018). Lietuvos Respublikos elektroniniu pinigu ir elektroniniu pinigu istaigu įstatymo Nr. XI1868 pakeitimo istatymas (XIII-1094). seimas.lrs.lt/portal/legalAct/lt/TAD/dbe23950488011e89197e1115e5dbece/KnGurqIGeD?positionInSearchResults=2\& searchModelUUID=b12ba5d1-1a92-405d-b771-123d20928ad2

Love, J. (2007). Artificial Neural Networks. In Process Automation Handbook (pp. 929-943). https://doi.org/10.1007/978-184628-282-9_109 
Madan, I., Saluja, S., \& Zhao, A. (2015). Automated Bitcoin trading via machine learning algorithms. http://cs229.stanford.edu/proj2014/Isaac Madan, Shaurya Saluja, Aojia Zhao,Automated Bitcoin Trading via Machine Learning Algorithms.pdf

Mahdavifar, S., \& Ghorbani, A. A. (2019). Application of deep learning to cybersecurity: A survey. Neurocomputing, 347, 149-176. https://doi.org/10.1016/j.neucom.2019.02.056

Mai, F., Shan, Z., Bai, Q., Wang, X. (Shane), \& Chiang, R. H. L. (2018). How does social media impact bitcoin value? A test of the silent majority hypothesis. Journal of Management Information Systems, 35(1), 19-52. https://doi.org/10.1080/07421222.2018.1440774

Platanakis, E., \& Urquhart, A. (2019). Portfolio management with cryptocurrencies: The role of estimation risk. Economics Letters, 177, 76-80. https://doi.org/10.1016/j.econlet.2019.01.019

Power, D. J. (2014). Using 'Big Data' for analytics and decision support. Journal of Decision Systems, 23(2), 222-228. https://doi.org/10.1080/12460125.2014.888848

Rebane, J., Karlsson, I., Denic, S., \& Papapetrou, P. (2018, August). Seq2Seq RNNs and ARIMA models for cryptocurrency prediction: a comparative study. Paper presented at the SIGKDD Fintech'18 (pp. 2-6).

Schueffel, P. (2017). The consise Fintech compendium. http://www.heg-fr.ch/FR/HEG-FR/Communication-etevenements/evenements/SiteAssets/Pages/patrick-schuffel/Schueffel (2017) The Concise Fintech compendium.pdf

Selman, S. (2012). Distinction of the authors of texts using multilayered feedforward neural networks. Southeast Europe Journal of Soft Computing, 1(1). https://doi.org/10.21533/scjournal.v1i1.82

Sun, X., Liu, M., \& Sima, Z. (2020). A novel cryptocurrency price trend forecasting model based on LightGBM. Finance Research Letters, 32, 101084. https://doi.org/10.1016/j.frl.2018.12.032

Talo, M., Baloglu, U. B., Yıldırım, Ö., \& Rajendra Acharya, U. (2019). Application of deep transfer learning for automated brain abnormality classification using MR images. Cognitive Systems Research, 54, 176-188. https://doi.org/10.1016/j.cogsys.2018.12.007

Tang, A., Tam, R., Cadrin-Chênevert, A., Guest, W., Chong, J., Barfett, J., ... Shabana, W. (2018, May 1). Canadian association of radiologists white paper on artificial intelligence in radiology. Canadian Association of Radiologists Journal, 69, 120135. https://doi.org/10.1016/j.carj.2018.02.002

Theblockcrypto.com. (2019). Bitcoin has been the most volatile and best performing major cryptocurrency in June - The Block. https://www.theblockcrypto.com/linked/29595/bitcoin-has-been-the-most-volatile-and-best-performing-majorcryptocurrency-in-june

Torres, G. D., \& Qiu, H. (2018). Applying recurrent neural networks for multivariate time series forecasting of volatile financial data (pp. 1-10). https://www.researchgate.net/project/Applying-Recurrent-Neural-Networks-for-MultivariateTime-Series-Forecasting-of-Volatile-Financial-Data

Tran, D., Mac, H., Tong, V., Tran, H. A., \& Nguyen, L. G. (2018). A LSTM based framework for handling multiclass imbalance in DGA botnet detection. Neurocomputing, 275, 2401-2413. https://doi.org/10.1016/j.neucom.2017.11.018

Zhong, G., Ling, X., \& Wang, L. (2018). From shallow feature learning to deep learning: Benefits from the width and depth of deep architectures. Wiley Interdisciplinary Reviews: Data Mining and Knowledge Discovery, 9(1) https://doi.org/10.1002/widm.1255

\title{
FORECASTING OF DIGITAL CURRENCY PRICES USING DEEP LEARNING ALGORITHM
}

\author{
Nijolè MAKNICKIENĖ, Kristina MIŠKINYTĖ
}

\begin{abstract}
Cryptocurrencies are still a novelty in the financial market which is not fully explored yet. This makes cryptocurrencies an interesting and relevant topic for researchers, regulators and investor. The cryptocurrency market is constantly growing, volatile and ever-changing, making it extremely risky for investments. Financial literacy, long-term prescience and correct focus without getting lost in chaos of risk, value and unpredictability are especially important in today's economy. Due to complex nature of the cryptocurrency market the large amount of profile data is generated, which can be processed using a variety of methods such as statistical, technical, sentiment, solution and other analysis. Previous studies have used two main method for cryptocurrency prices prediction: empirical and machine learning algorithm analysis. The aim of this article is to test the applicability of LSTM deep learning algorithm for cryptocurrency price forecasting as well as to evaluate the results. The research results showed that deep learning algorithm are able to forecast with low error magnitude, moreover trend of predicted values is accurate when compared to observed values. The results suggest that deep learning algorithm application for forecasting of cryptocurrency market price is a suitable alternative for risk minimization.
\end{abstract}

Keywords: artificial intelligence, deep learning, LSTM, forecasting, cryptocurrencies, cryptocurrencies market. 